\title{
Media Engagement with the Abuse and Deception Narrative in the Church in Zimbabwe: A Critical Discourse Analysis
}

\author{
Nhlanhla Landa \\ ORCID iD: https://orcid.org/0000-0002-0037-0218
}

\section{Sindiso Zhou}

ORCID iD: https://orcid.org/0000-0002-4267-8456

\section{Abstract}

This article grapples with the trending subject of abuse and deception of women and girls in the church in Zimbabwe. The relationship between religion, abuse and deception is complicated by the notion that 'things religious are things pure', which leads to the violation and exploitation of congregants. This article focuses on media engagement with abuse and deception narratives of women and girls by church leaders. Using the Critical Discourse Analysis and Agenda Setting theories, the study analyses media reportage of abuse and deception of women and girls in the church in Zimbabwe. We also reflect on how the justice system restricts newsmakers in the reportage of court cases. Findings indicate that besides, and because of, the restrictions of ethics of court reporting, the focus of the media is limited to scandals, and naming and shaming, without critically engaging with the underlying issues. Media coverage of abuse and deception in the church is insufficiently investigative and inadequately long-term oriented. The study concludes that the media have not sufficiently explored the link between abuse, deception and critical determinants, namely poverty and socio-economic decline. This has largely been caused by the media's obsession with hard news, which is limited in scope and flexibility in its engagement with issues and is largely restricted by ethics. It has also been because of the stringent restrictions imposed by the legal system on court reporting. We recommend a reorientation of media engagement with 
the religious exploitation of women narrative. The first step towards this reorientation is featurisation of the women abuse and deception story.

Keywords: Women and girl abuse, poverty, deception, media, ethics

\section{Introduction}

Abuse of women, especially of a sexual nature, is a growing concern worldwide. Southern Africa has also suffered in this area (Win 2000; Gqola 2015; Sibanda-Moyo, Khonje \& Brobbey 2017). Some research has been done specifically on the relationship between crime and the church, and the relationship between crime and religion in general (Bromley \& Cress 2000; Cooper 2002; Fortune 2002). It would seem the church is a rich place for crime, especially against women and girls. As a result, the media are awash with headlines of religion-related violation women and girls, both internationally (CBS News 2018; BBC News 2018; RTE News 2018; CRX 2018) and locally (NewsDay 2017a; NewsDay 2017b). It is the argument of this article, however, that media engagement with the women and girls' abuse and deception is still insufficient, and has not been one that puts the abuse of women on both the media and public agendas.

Politics, the economy and sports have been the predominant issues the media in Zimbabwe deal with in the past two decades. Several political and economic developments have influenced this poised focus on these issues. What this has resulted in is a neglect of other, and equally important, issues of social concern such as the environment, crime in general (which rises with depreciating socio-economic status of a nation), crimes against women and children and social development. Where these are given attention by the media once in a while, they are either sensationalised or trivialised. According to Agenda Setting (McCombs \& Shaw 1972), this has the effect of relegating such issues to the periphery of the agenda of the public. We argue in this article that once this happens to the issue of violence against women, the effect is perpetuation of abuse and deception of women even in the church.

This article analysed the media coverage of issues relating to the trending subject of abuse and deception of women and girls in the church in Zimbabwe. The depth, frequency and quality of the stories published by the mass media in Zimbabwe were the major focus of the analysis in the article. 
The analysis was framed within a Critical Discourse Analysis (CDA) and an Agenda Setting lens. The basis of CDA is its focus on language use in practical social situations and contexts, while Agenda setting is concerned with establishing the link between the media agenda and the public agenda.

\section{Literature Review}

The power of the media in influencing society is indisputable, and has been given attention by a number of researchers in the recent past (Landa 2014; Hobbs 2008). Specifically, Hobbs observes that regimes of truths become true as far as the media project them to be, while Landa insists that the practice of journalism is characterised by the subjective selection of some elements as newsworthy and leaving out some as unimportant. Both arguments presented above project a case for the agenda setting role of the media. As Vangshardt (2009) and Graber (2006) submit, the media have the power to control public discourse. We hold that the media have the power to influence public opinion and, therefore, public agenda.

\section{Correlation of Media Agenda and Public Agenda}

Several studies have been carried out on the apparent relationship between media agenda and public agenda. These include Golan and Wanta (2001), Johnson, Wanta and Boudreau (2004), Tedesco (2001), Kwansah-Aidoo (2003) and Fico and Freedman (2001). Kim and Lee (2006) have revisited agenda setting in the age of cyberspace. Furthermore, Scheufele and Tewksbury (2007) specifically focused on developing and refining the agenda setting theory, while Young and McCarthy (2009), among others, extend the theory beyond elections, the specific field that it was originally applied to by McCombs and Shaw (1972), Becker and McCombs (1978), King (1997) and McCombs, LopezEscobar and Llamas (2000).

In the original conceptualisation of agenda setting (McCombs \& Shaw 1972), it was argued that the media play the role of putting at the fore certain issues and downplaying others. They argue that 'the information in the mass media becomes the only contact many have with politics' (McCombs \& Shaw 1972 ; 176) and indeed with many issues of interest in the media in our day. Thus, opinions many strongly hold in relation to issues of interest and the decisions they make as a result are influenced by the media. This way, the 
media agenda strongly influences the public agenda; how the public think and feel about specific issues and/or specific individuals.

McCombs and Valenzuela (2007) have recorded a case of successful agenda setting by a Chilean magazine that exposed child pornography, which led to a chain of events that included several arrests, public campaigns and the enactment of legislations against child pornography. This is a case of extending agenda setting beyond politics and elections. Agenda setting has also been applied to environmental issues (Cohen 1975; Zhou, Landa \& Zhou 2017), and to human trafficking (Papadouka, Evangelopoulos \& Ignatow 2016). This study extends agenda setting to the women abuse and deception narrative.

\section{Court Reporting}

Court reporting is generally a difficult sub-genre in journalism. It often comes with a lot of restrictions around publication of information relating to cases before the courts. In many states, reporters are restricted in their reporting of court cases as they are often not allowed to report on prior convictions of an offender or alleged offender under trial (Supreme Court Tasmania 2015: 7). Reporters need to be careful not to report on anything that can affect the accused, complainants and witnesses. Court reporters also often receive nonpublication orders in relation to certain cases. For example, in Tasmania 'reporters should be careful not to background the case beyond what is told the jury' (Supreme Court Tasmania 2015: 7). The Supreme Court Tasmania (2015: 4) states that reporters cannot report on anything said in the absence of the jury as this amounts to contempt of court, even if it was said in court during a trial, 'If there is anything newsworthy or interesting arising from the voir dire, it must wait until after the trial is over, and there is no longer a risk of the jury hearing material which has been excluded'.

In Zimbabwe, Feltoe (2002) indicates that reporting on material that is likely to prejudice either party in a case before the courts amounts to contempt of court. The media may run into trouble with the law when it writes subjecttively about a case that is already underway or is about to go to court (Feltoe 2002: 9). The threat of being charged with contempt of court hovers above the heads of court reporters, limiting them to reproduce what would have been said in the courts of law. Even when a case has ended and the plea period has come and gone, reporters are unable to pursue cases beyond the court ruling. 


\section{Women Abuse in the Church}

In a study in Canada, Flynn (2003) established that chances of sexual harassment of women were higher in the church than at the workplace. Often, very few of the victims report their abuse to authorities in their churches and even fewer to the police (Stacey, Darnell \& Shupe 2000). With the rate at which ministries and churches are sprouting, in many instances there are no other religious authorities to report to, as the church or ministry is owned by the abuser or their family. Even when they report, women often run the risk of not being believed, leading to shame and isolation, which in turn, have led some to commit suicide (Benyei 1998). Whether the perpetrator is a predator, wanderer or lover type, as classified by Grenz and Bell (2001), they often isolate their victims from their family and make them believe they are the source of comfort and solution to their problems.

Brown and Parker (1989) indicate that the major cause of abuse of congregants by the clergy is the belief that since Jesus suffered and died on the cross to redeem humanity, suffering or self-sacrifice of Christians is equally redemptive and is therefore not something to be rejected. This, as 'Minister and Clergy Sexual Abuse Survivors' chair Margaret Kennedy (n.d.: 2) observes, makes survivors of abuse believe their suffering is not a bad thing, as they are merely carrying their crosses. We hold that this puts the victim at the mercy of the perpetrator of abuse, and in religious settings it is even more challenging, as the abuser often claims to speak and act on behalf of or upon the instruction of God, which makes it difficult for the congregants to challenge. Women and girls are also often threatened with evil spirits (Landa, Zhou \& Tshotsho 2019). It is usually only much later that they realise the religious leader abused his power and betrayed their trust (Fortune 2009). However, Fortune insists, as long as there is no mutuality, lack of choice, inequality and fear, no meaningful consent can be talked about.

Religion in Zimbabwe has recently surged to previously unprecedented growth levels (Landa \& Zhou 2018). Much more than previously, as a result, religion has emerged as a lived reality for many Zimbabweans. The worsening economic conditions, over the last twenty years, but especially over the past decade, have seen many people turning to the church, which, as Zhou, Pfukwa and Landa (2018) indicate, has promises for better days for the multitudes facing unemployment and other economic challenges. This has increased women and girls' vulnerability to abuse and deception by religious leaders. 
And the church has not done much to help,

either by its silence or its instruction, the church has too often communicated to battered women that they should stay in abusive relationships, try to be better wives, and 'forgive and forget' (Fortune \& Enger 2005).

This has translated into practice, even when the abuse involves the clergy and women and girls who are not necessarily their wives.

\section{Women Abuse and the Media in Zimbabwe}

The abuse of women and the media challenge in Zimbabwe are multifaceted as they relate to access, space, representation, visibility, participation, language and interpretation (Morna 2002). Abuse of women relates to,

... any act of gender-based violence that results in, or is likely to result in, physical, sexual or psychological harm or suffering to women, including threats of such acts, coercion or arbitrary deprivation of liberty, whether occurring in public or private life (United Nations 1993).

According to Morna (2002: 7),

violence against women is either not reported at all because it is seen to take place in the private sphere, or reported in bizarre and sensationalist ways that invariably place the blame on the victim.

Morna further argues that the news stories pay no attention to women's human rights abuse in their coverage of abuse cases.

Often, the media re-victimise the victims through sensationalising and scandalising their stories. Women are often presented as prostitutes and golddiggers (Gadzekpo 2011). Women are often underrepresented and misrepresented by the media, and the media also often reinforce gender stereotypes (Global Media Monitoring Project 2010) that are not favourable to women. According to the Gender and Media Baseline Study (GMBS 2003), even in gender justice and gender violence issues, men were better heard than women. 


\section{Methodology}

The study employed a qualitative approach. We were interested in the narratives of victims as reported by news articles. The qualitative approach sits well with narratives, as it interests itself with studying phenomena in their natural settings (Babbie 2010). We used a sample of 23 news articles drawn from several newspapers, one online news source, and one television station in Zimbabwe. These were taken off the internet and were published between the year 2010 and 2018. The articles were drawn from NEWSDAY, The Herald, NEWS24, ZBC NEWS ONLINE, The Standard, Chronicle and The Sunday Mail. The newspaper medium was chosen for its ability to dedicate more space to news articles than other media. Textual analysis, as done in critical discourse analysis, allows for in-depth analysis of texts and narratives, yielding comprehensive and multiple thematic strands for interpretation; thus, the sample size of 23 news articles was sufficient. The basic assumption of the study was that featurisation of the story of women abuse had better results in raising awareness of violence against women and girls.

\section{Theoretical Framework}

The study relied on a dual lens of the Critical Discourse Analysis (CDA) and Agenda Setting theories. The potency of CDA lies in that it 'serves as both a theoretical framework and a method of analysis' (Zhou et al. 2017). What makes CDA relevant for this study is its centralisation, in analysis, of the sociocultural contexts in which news texts occur (Bell 1998). Furthermore, the CDA approach interests itself with the social reality behind news texts, such as power relations and ideological positions (Van Dijk 1988a; 1988b; Fairclough 1995); beneficiaries of the version represented by what is said (Starosta 1999), and the identities of all involved (Pietikainen \& Hujanen 2003).

Agenda setting, on the other hand, interests itself with how the media hold the power to influence the public's perception on issues of social interest. The media thus bring to light chosen issues that would otherwise remain in the dark (Perloff 1998), and similarly keep in the dark issues that they (the media) adjudge as better kept away from public consumption. As the media stress certain issues over others (Wanta 1997), select certain content as more newsworthy than others (Landa 2014), and thus influence the public agenda (Kaid 2004), they are agenda setting.

The media, therefore, have the power to direct people towards what to 
think about (Trent \& Friedenberg 2008; McCombs 2004). Balmas and Sheafer (2010) add that agenda setting also relates to how the media determine how to think about certain issues emphasised on the news. Weimann and Brosius (2017) submit that 'the salience of elements on the news influences, in turn, their salience on the public agenda'. This is also shared by Weaver (2007). Weaver, McCombs and Shaw (2004) dispute the contention that researchers have unnecessarily expanded agenda setting. What seems to be clear, however, is that the internet and the new media associated with it are changing the implications of agenda setting, as social media users can easily set their agendas (McCombs 2005; Ragas \& Roberts 2009; Chaffee \& Metzger 2001).

\section{Analysis}

For easy reference, the news articles sampled have been labelled A1 (Article one) to A23 as indicated below:

A1 - Pastor gets 60 years for preying on congregant (NewsDay 3 November 2017)

A2 - HIV+ pastor caged 18 years for raping congregant (NewsDay 15 December 2017)

A3 - Senior AFM pastor faces 5 counts of rape (NewsDay 26 August 2016) A4 - Vic Falls pastor jailed for rape (NewsDay 25 January 2013)

A5 - 'Rapist' pastor granted bail

A6 - AFM pastor's rape case crumbles

A7 - Methodist pastor acquitted of rape (NewsDay 13 April 2017)

A8 - Zimbabwean Pastor gets 50 years for rape (NEWS24 03 February 2014)

A9 - Drama at Magaya rape trial (NewsDay 04 April 2018)

A10 - Magaya charged with rape (NewsDay 20 August 2016).

A11 - Prophet Magaya arrested on rape charge (Towindo \& Matabvu 2016) A12 - I was never raped: Magaya accuser (Rupapa 2016)

A13 - Prophet 'rapes' sister-in-law to cleanse goblins (Chiramba 2018).

A14 - Self-styled prophet accused of rape (The Herald 01 January 2018)

A15 - 'Rapist' Pastor Gumbura owns every woman in his church, Court told (Newsday 13 December 2018)

A16 - Gumbura church saga: ACCZ under spotlight (ZBC NEWS ONLINE 6 February 2014) 
A17 - State witness chickens out of Magaya rape trial (NewsDay 30 March 2018).

A18 - Goba 'burns his fingers' in Magaya rape trial (NewsDay 7 June 2018)

A19 - Magaya case: Goba to lodge criminal report (NewsDay 6 April 2018)

A20 - Burglars steal Magaya court documents (NewsDay 5 April 2018)

A21 - 'Sexual healing' pastor up for rape (The Herald)

A22 - We expect salvation, not rape in church (The Herald)

A23 - Churches no longer safe for women (Mugugunyeki 2014).

The researchers were pre-occupied with a number of questions in analysing the sampled texts. These questions included:

1. How does the news story put the women abuse and deception narrative on the media agenda to put it on the public agenda?

2. Is the news story analytical?

3. Does the news story go beyond the event and raise the underlying issues; is it in-depth?

4. What is the frequency with which the story about the abuse and deception of women is reported?

5. What issues and key terms characterise the news story?

The sampled articles display a number of weaknesses. We found most of them lacking in depth, and limited just to the narration of court proceedings. Analysis indicated that most news articles on clergy sexual abuse emanated from the courts and the coverage, both in terms of depth and of frequency, was limited to the court sittings and evidence presented by attorneys and witnesses. Our analysis was limited to the news articles, and did not go beyond to understand why the stories were fashioned in the way they were. We were aware, nonetheless, that news stories around cases in court were guided and restricted by a number of legal systems, ethics and instruments.

\section{Depth of News Articles}

As Morna (2002: 5) indicates, depth of news articles relates to 'the sources consulted, the extent of investigation and inquiry, and the ability to use a gender lens to uncover hidden stories, context and balance'. Analysis of the data indicates that most of the news articles sampled for the study emanated 


\section{Nhlanhla Landa \& Sindiso Zhou}

from the courts. Only when the accused was a prominent figure in society did the story emanate from other sources, like the police and eye-witness accounts. Even in such, the stories took a scandal stance. Evidence of the sources of the articles is seen in the attribution in the articles. Attribution in the vast majority of the stories is in the following phrasing:

According to court papers, ...

During trial, the court heard that ...

The court was told that ...

The State alleges that ...

According to prosecutors ...

Prosecutors allege that ...

The court heard that ....

What this indicates is that on their own, reporters have not done much in the direction of exposing the abuse of women and girls in the church. Before stories are reported to the police, the media have not engaged with communities in as far as this narrative is concerned; the media have not put the women abuse narrative on their agenda. While it is a golden rule that journalists are not supposed to interfere with, and unduly influence proceedings in the court, there is no policy stopping the media practitioners from exposing rape cases and all other forms of abuse of women in cases that have not been brought before the courts. The media have also been reluctant to investigate cases that have been concluded by the courts. Furthermore, reporters do not follow up on cases that have been withdrawn by complainants to expose circumstances surrounding the cases and leading to complainants withdrawing cases against the accused. However, it would seem that beyond the details provided by the court, journalists are neither able, nor interested to dig further.

Only when investigations are done around the cases and reported can the issue of women abuse take a pole position on the media agenda, be successfully put on the public agenda and influence public behaviour. Reproducing, or at best narrating, what is said in the arguments in court would not put the women abuse issue on the public agenda; establishing the underlying issues, the issues the court has not heard, would. For example, in the case covered under the headline Drama at Magaya rape trial (NewsDay 04 April 2018), in which the complainant later dropped charges and withdrew the case claiming she had falsely accused the alleged perpetrator, what would put the women 
abuse narrative on the public agenda are details on the following set of questions relating to the case in question:

1. Why did the complainant falsely accuse the alleged perpetrator?

2. Did the complainant not rightly accuse the alleged perpetrator and later change her mind? If so, why did she change her mind?

3. The state had lined up six other witnesses; what were they going to say? Had they also changed their minds about testifying? If so, why?

4. To what extent is the state's allegation that 'Magaya deposited $\$ 100,000$ into the complainant's bank account, allegedly to induce her to drop charges' (News Day 04 April 2018) true?

5. How many other women and girls have withdrawn cases of abuse before the courts and what have been their reasons?

6. In what circumstances can the state, in the interest of justice, continue with a case in which the complainant or the major witness has withdrawn from the proceedings?'

7. What charge(s) can the court lay against a complainant who reports a case and decides to withdraw it when it goes on trial?

The answers to these questions in the media would give the narrative of women abuse and deception a new position in the agenda of the public. However, in the absence of comprehensive media engagement with the narrative of women abuse and deception, many questions are left unanswered. Where an alleged victim drops charges, the public will be interested in knowing why. The public is left to process the stories and try to separate information from misinformmation. It is such fickle engagement or non-engagement by the media that causes the story of women to be dismissed easily.

Another example of lack of depth is in sample A8 (Zimbabwean Pastor gets 50 years for rape) (News24 03 February 2014). The story indicates that the accused 'claimed that all female members of his church were his wives by right, and married women were on loan from their husbands'. This is an important strand of the news article that deserves to be followed up outside what 'the court heard'. For instance, from such a story the public would want to know the following;

1. What do the unmarried women in the church think of the claim that by right they are all the pastor's wives? 
2. What are the feelings and beliefs of all the married men in the church whose wives are 'on loan' to the leader?

3. Are there no unreported cases of women, married and unmarried, who had been sexually abused in the belief that the pastor had a right to be intimate with them all?

4. What were the beliefs and sexual behaviours of all the pastors in the branches of the church in other towns and cities throughout the country?

5. What does the ordinary Zimbabwean in the street think of the claims that every unmarried woman in the church is, by right, their pastor's wife?

6. What sexual behaviours do such beliefs promote in the country in general and in the church in particular?

Serious engagement with this case beyond the court proceedings and after the conclusion of the case would expose the rot not only in the particular church, but also in other churches and cults-cum-churches that share the same, or similar, beliefs. Engagement with such important questions would give the story about women abuse a key position in both the media and public agendas. In the excerpt below, the reader is left with questions on the fate of the accomplice. The excerpt reads;

The court heard upon arrival the woman entered into Maurukira's residence together with the convict's friend, Kudakwashe Rwodzi, who locked the door from outside and promised to return after a few minutes.

Maurukira then took out a bottle of anointing oil and instructed the woman to comply with his orders, claiming her spiritual attacks would return if she did not.

Maurukira pushed the woman onto his bed and raped her (A1: NewsDay 3 November 2017).

Mentioning that the convict's friend locked the door from outside and moving on with the story without ever mentioning the friend, who is an obvious accomplice, is hardly enough for the reader. However, because the particular case the reporter is covering is specifically on the convict, mention of the accomplice is only once and it is from its mention by the court. 
Pre-occupation in the stories seems to be with the sentences given to the convicted at the conclusion of trial as indicated in the headlines below:

Methodist pastor acquitted of rape (A7: NewsDay 13 April 2017).

Zimbabwean pastor gets 50 years for rape (A8: NEWS24 03 February 2014).

Pastor gets 60 years for preying on congregant (A1: NewsDay 3 November 2017).

HIV+ pastor caged 18 years for raping congregant (A2: NewsDay 15 December 2017).

In the following story lead,

A 70-year-old pastor with an apostolic sect from Victoria Falls was on Wednesday jailed for 15 years for raping his 12-year-old niece several times (A5: NEWSDAY 25 January 2013).

Further, pre-occupation also seems to be on bizarre circumstances surrounding sexual abuse of women in the church. Examples are the following headlines,

Prophet 'rapes' sister-in-law to cleanse goblins (A13: Chronicle 04 January 2018)

'Rapist' Pastor Gumbura owns every woman in his church, Court told (A15: NewsDay 13 December 2018)

'Sexual healing' pastor up for rape (A21: The Herald)

An example of a story lead that focuses on the uncanny is excerpted below,

A 50-YEAR-OLD prophet from Bulawayo has appeared in court for allegedly raping his sister-in-law while her husband was in prison after having first suggested that her private parts needed to be cleansed as goblins were bedding her (A13: Chronicle 04 January 2018).

However, attention is rarely on the victim or the complainant, not even on secondary victims. While ethically the identities of alleged victims are protected in reporting rape cases, merely stating their ages removes the person aspect 
of victimhood. Of the 23 articles sampled in this study, only one article is on the alleged victim, the major reason being that she had contributed to a major shift in the case by withdrawing her case and threatening to approach the Law Society of Zimbabwe to institute a disciplinary hearing against the Prosecutor General for wanting to proceed with the case after she had withdrawn the case. In other words, she is a hero in the story for threatening to prosecute the Prosecutor General, a major turning of tables.

Further, communities are absent in the reporting of court cases. While ethics demand that the identities of victims of rape and their families cannot be revealed for their protection, there is no policy against seeking their feelings, views and voices on the issues involved. For example, a section in one news article reads,

A MUTARE-BASED Methodist Church in Zimbabwe pastor was last Friday acquitted of rape charges levelled against him after the complainant's witnesses gave contradictory statements (A7: NEWSDAY 13 April 2017).

Regardless of the case being concluded, the reader is obviously still interested to know what the conflicting statements by the witnesses were, and what the church elders referred to in the story, and what other congregants and the community in general said and felt about the whole alleged crime. This would help put the story of the women abuse on the public agenda. We hold that the absence of the voices of community members and people close to the victims of crimes excludes families and communities from the women abuse narrative and relegates the narrative to a matter for the courts and for the media, since the media only give voice to the alleged perpetrators and their representatives. The state, in most cases, is the voice of the victims.

It would seem that featurisation of the story of women abuse gives it more depth, space and focus, and gives the reporter the flexibility to bring women's voices into the story. One example of a feature that gives depth and is likely to institute debate around the women abuse and deception story is headlined;

Church no longer safe for women (The Standard 19 January 2014).

The reporter goes on to document several dimensions of the women abuse 
story, in the process also referring to cases both before the courts and being dealt with by the police and the Apostolic Christian Council of Zimbabwe (ACCZ). A section of the story reads,

Abused women are always in a quandary. Their abuse by pastors, often during spiritual or marital counselling sessions wins little public attention and they are often held responsible for the relationship ... Pastor Gumbura was seen as being above reproach and the victims are now viewed as the 'seductresses' who tempted the man of God into a sexual relationship (A23: The Standard 19 January 2014).

The feature allows a report space, and a reporter time to investigate several issues related to the subject at hand.

The other feature (A22) in the sample also takes a look at a number of critical issues that seek to spark debate around the abuse of women. For example, sections of the feature read,

Is it a search of wonder workers, visionaries or riches that is making people not see the light? Day in day out church leaders are being made to stand in the dock over accusations of deflowering maidens in church, impregnating married women and even stealing from members of their flock...

Just like driving a car, checks and balances and even a competence test must be demanded for someone to lead a church.

Church leaders must possess certain qualities to ensure their doctrines do not poison the religious communities they lead. Lack of leadership qualities affects the way people worship and erodes confidence in God...

The Bible lists qualities which church leaders must have ... (The Herald).

As indicated above, a feature allows the reader to express opinions and comment on issues they would otherwise not comment on.

Without featurisation of the story of women abuse, and due to stringent court reporting regulations and ethics, hard news forces reporters to stick to what is said in court and to include trivial material that adds no value to the women abuse narrative. Examples include, 
Magaya arrived at the court uncuffed in a double-cab vehicle and escorted by two police detectives. He chuckled as photojournalists captured him entering the building where some of his congregants knelt and greeted him as he walked into Court 6. Sporting a blue shirt, black trousers and black shoes, Magaya appeared relaxed and occasionally chatted with a Zimbabwe Prisons and Correctional Services officer as his wife sat in the gallery (A11: Sunday Mail 21 August 2016).

Magaya arrived at the courts after courts had already closed and the magistrates had to be recalled from home (A10: NewsDay 20 August 2016).

This backgrounding does not add value to the women abuse narrative. If anything, it projects the accused as a confident hero who, even in such 'difficult' times was chatty and was worshipped by congregants from his church. The second excerpt serves the same; even magistrates had to change from their home clothes and return to work because an important person had been arrested. However, without the trivial backgrounding, in hard news reporters will be forced to write three-sentence news articles. For example, if we remove the second excerpt above from the story where it is excerpted from, the story remains with only three sentences as indicated below;

PROPHETIC Healing and Deliverance Ministries (PHD) leader Walter Magaya has been arrested and arraigned before the courts on allegations of raping a 25 year old woman last year in July. Magaya was arrested on Friday night and detained at Rhodesville police station. He appeared before magistrate Vakai Chikwekwe who granted him \$2,000 bail coupled with stringent reporting conditions (A10: NEWSDAY 20 August 2016)

Such stories are a result of both stringent court reporting ethics and lack of innovativeness on the part of the reporter. The reporter's target reader would seem to be those people who know who Magaya is. The assumption is that every reader knows who Magaya is. The article makes no effort to explain the brevity of the story and the lack of details on the alleged crime.

We also did a key term scanning of the articles. We drew up a total of ten terms that are key in the narrative of the abuse of women and girls and 
checked the frequency of their use in the media reportage of sexual abuse of women and girls by the clergy. These included gender-based violence, violation, trauma, traumatised, horrific, violence against women, social problems, brutality, suffering, and sexually transmitted infections. We hold that these sets of terms take the women abuse story into the media agenda and, by extension, the public agenda. For example, the conception of rape of women and girls in the church as gender-based violence, violence against women, traumatic, horrific, a social problem, brutal, causing untold suffering, transmitting several infections, and a general violation of women and of their human rights, position the women and girls abuse narrative an important and strategic angle in the public agenda.

Analysis indicated that of all the 23 news articles, none refers to gender-based violence, violation, trauma, human rights, horrific, brutal, suffering, and sexually transmitted infections. Only one article refers to rape cases as violence against women, while another one refers to leadership problems in the church, which remotely relates to the key term 'social problem'. Furthermore, data indicate that articles A22 and A23, which refer to violence against women and social problems respectively, are features. This reinforces the fact that featurisation of the women abuse story gives the newsmakers flexibility and space to explore the issues from different angles.

\section{Discussion}

Analysis of data indicated that media engagement with the narrative about women and girls is insufficient and fickle. This is caused both by stringent court reporting regulations and ethics as well as reluctance by the media to investigate stories that have either been concluded by the court or withdrawn by complainants. The major problem, to start with, is the media's reliance on the court for coverage of women abuse by the clergy. Without the court cases, it would seem there is no coverage of women abuse issues, except by a few features and opinion pieces.

Lack of depth and inadequate sourcing trivialise the women abuse story. It is difficult for the reader to attach importance to a story that has too many gaps. In essence, the reader remains with so many unanswered questions. These unanswered questions represent gaps in a story. Often, there is not even effort to acknowledge these gaps by the newsmaker, the acknowledgement that would otherwise be represented by such statements as, 
Efforts to get details from the PG's office on the state's claim that it has evidence that Magaya paid \$100 000 into the alleged victim's bank account were fruitless as the PG said revealing the details to the public would prejudice the defence's case (Creation by researchers).

Without such framing, stories lend themselves to the criticism that they are cursory, lack depth and have too many gaps. There obviously are other sources than the court on the cases of the abuse of women.

Media engagement with the women abuse and deception narrative is weak and superficial at best. Declaring that 'cases of church leaders abusing women are common in Zimbabwe' without engaging with, for example, what the justice system is doing to nip the problem in the bud, or how the problem has affected the community, spirituality or women and girls in particular is inadequate. The media engagement with the women abuse narrative has therefore not painted rape and sexual assault of women and girls by the clergy as a social problem that needs the urgent and undivided attention of the society.

\section{Conclusions}

Given the gravity of the deception of women, leading to their sexual abuse in the church and the ideal that this issue should be on the public agenda, we concur with Vangshardt (2009: 20) that,

if the media over a prolonged period of time cover certain issues more than others it will, theoretically at least, create correlation between the media agenda and public agenda.

However, successfully setting an agenda for the public goes beyond that. It further needs to include the question of framing, and following up on issues to their logical conclusion. Therefore, agenda setting involves frequency, consistency, quality of coverage of issues of social import and the credibility rating of the sources of salient issues. The media's setting of an agenda for the public, is a deliberate exercise that begins with the media seting goals to be achieved.

Absence of the voices of families and communities in the news articles on sexual crimes committed by the clergy against women and girls does not make the women abuse and deception narrative a social, or at least community 
problem. We conclude that as long as the media do not raise the narrative about the abuse of women and girls to the magnitude that warrants it to be considered as a social problem, it will be difficult for it to find a spot in the public agenda. Hurried, and often comic, narrations of what takes place in court would not achieve this magnitude. Instead, investigative feature articles that give space to a multiplicity of voices, especially voices of the women who are mostly victims in these crimes, would.

\section{References}

Babbie, E. 2010. The Practice of Social Research. Cape Town: ABC Press. Balmas, M. \& T. Sheafer 2010. Candidate Image in Election Campaigns: Attribute Agenda Setting, Affective Priming, and Voting Intentions. International Journal of Public Opinion Research 22,2: 204-229. https://doi.org/10.1093/ijpor/edq009

BBC NEWS. 16 August 2018. Pope Francis on Side of Victims of 'Predator'

Priests in US. Available at: https://www.bbc.com/news/world-us-canada45211942 (Accessed on 27 March 2019.)

Becker, L. \& M. McCombs 1978. The Role of the Press in Determining Voter

Reactions to Presidential Primaries. Human Communication Research 4: 301-307. https://doi.org/10.1111/j.1468-2958.1978.tb00716.x

Bell, A. (ed.). 1998. Approaches to Media Discourse. London: Blackwell.

Benyei, C.R. 1998. Understanding Clergy Misconduct in Religious Systems: Scapegoating, Family Secrets, and the Abuse of Power. New York: Haworth Pastor Press.

Bromley, D.G. \& C.H. Cress 2000. Narrative of Sexual Danger: A Comparative Perspective on the Emergence of the Clergy Sexual Violation Scandal. In Shupe, A., W.A. Stacey \& S.E. Darnell (eds.): Bad Pastors: Clergy Misconduct in Modern America. New York: New York University Press.

Brown, J.C. \& R. Parker 1989. 'For God so Loved the World?' In Brown, J.C.

\& C.R. Bohn (eds.): Christianity, Patriarchy and Abuse: A Feminist Critique. $1^{\text {st }}$ Edition. New York: Pilgrim Press.

CBSNEWS 2018. Pope Francis to Meet Victims of Sexual Abuse in Ireland. CBS/AP 21 August 2018, 8:42 AM. Available at: https://www.cbsnews.com/ news/pope-francis-catholic-church-meetvictims-of-sexual-abuse-in-ireland-today-2018-21-08/ 
(Accessed on 25 August 2018.)

Chaffee, S.H. \& M.J. Metzger 2001. The End of Mass Communication? Mass Communication and Society 4: 365-379.

https://doi.org/10.1207/S15327825MCS0404_3

Chiramba, S. 2018. Prophet 'Rapes' Sister-in-law to Cleanse Goblins.

Chronicle. Available at: https://www.chronicle.co.zw/prophet-rapessister-in-law-to-cleanse-goblins/ (Accessed on 27 March 2019.)

Cohen, D. 1975. A Report on a Non-election Agenda Setting Study. Paper presented to the Association for Education in Journalism. Ottawa, Canada, 1975.

Cooper, D. 2002. Desiree Cooper: Encounter with her Minister Broke Trust, but not Faith. Available at: http://www.freep.com/news/metro/des28 29920328.htm (Accessed on 25 August 2018.)

CRUX 2018. Pope Opens Chile Trip with Apology for Clerical Sexual Abuse.

16 January. Available at: https://cruxnow.com/pope-in-chile-andperu/2018/01/ 16/pope-opens-chile-trip-apology-clerical-sexual-abuse/ (Accessed on 25 August 2018.)

Fairclough, N. 1995a. Critical Discourse Analysis: The Critical Study of Language. London: Longman.

Fico, F. \& E. Freedman 2001. Setting the News Story Agenda: Candidates and Commentators in News Coverage of a Governor's Race. Journalism \& Mass Communication Quarterly 78,3: 437-449.

https://doi.org/10.1177/107769900107800303

Flynn, K.A. 2003. The Sexual Abuse of Women by Members of the Clergy. Jefferson, NC: McFarland \& Co.

Fortune, M.M. 2002. Introduction: Forgiveness and Abuse. Journal of Religion \& Abuse 4,4: 1-5.

Fortune, M.M. 2009. Responding to Clergy Misconduct: A Handbook. Faith Trust Institute. https://doi.org/10.1300/J154v04n04_01

Fortune, M.M. \& C.G. Enger 2005. Violence against Women and the Role of Religion. Applied Research Forum, National Online Resource Center on Violence Against Women.

https://vawnet.org/sites/default/files/materials/files/2016-

09/AR VAWReligion 0.pdf

Gadzekpo, A. 2011. Battling Old Ghosts in Gender and African Media Research. African Communication Research 4,3: 389-410.

Gender and Media Baseline Study 2003. Regional Overview of the Gender and 
Media Baseline Study. Gender Links. Available at:

https://genderlinks.org.za/programme-web-menu/publications/genderand-media-baseline-study-2003-2005-06-30/

(Accessed on 27 March 2019.)

Global Media Monitoring Project 2010. Who Makes the News? GMMP Report. Available at: http://youcantbewhatyoucantsee.com/wpcontent/uploads/2013/07/Global-Media-Monitoring-Project-2010.pdf (Accessed on 27 March 2019.)

Golan, G. \& W. Wanta 2001. Second-level Agenda Setting in the New Hampshire Primary: A Comparison of Coverage in Three Newspapers and Public Perceptions of Candidates. Journalism \& Mass Communication Quarterly 78,2: 247-259.

https://doi.org/10.1177/107769900107800203

Gqola, P.D. 2015. Rape: A South African Nightmare. Johannesburg: JM Books.

Graber, D.A. 2006. Mass Media and American Politics. $7^{\text {th }}$ Edition. Washington: CQ Press.

Grenz, S.J. \& R.D. Bell 2001. Betrayal of Trust: Confronting and Preventing Clergy Sexual Misconduct. $2^{\text {nd }}$ Edition. Grand Rapids: Baker Books.

Hobbs, M. 2008. On Discourse and Representation: Reflections on Michel Foucault's Contribution to the Study of the Mass Media. Annual Conference of the Australian Sociological Association, University of Melbourne.

Johnson, T.J., W. Wanta \& T. Boudreau 2004. Drug Peddlers: How Four Presidents Attempted to Influence Media and Public Concern on the Drug Issue. Atlantic Journal of Communication 12,4: 177-199.

https://doi.org/10.1207/s15456889ajc1204_1

Kaid, L.L. 2004. Handbook of Political Communication Research. New Jersey: Lawrence Erlbaum Associates.

https://doi.org/10.4324/9781410610584

Kennedy, M. n.d. Christianity and Child Sexual Abuse - Survivors Informing the Care of Children Following Abuse. Child Abuse Review 9. https://doi.org/10.1002/1099-0852(200003/04)9:2<124::AIDCAR589>3.0.CO;2-L

Kim, S.T. \& Y.H. Lee 2006. New Functions of Internet Mediated Agendasetting: Agenda Rippling and Reversed Agenda-setting. Korean Journal of Journalism \& Communication Studies 50: 175-205. 
King, P.T. 1997. The Press, Candidate Images, and Voter Perceptions in Communication and Democracy. Mahwah, NJ: Lawrence Erlbaum Associates. Kwansah-Aidoo, K. 2003. Events that Matter: Specific Incidents, Media Coverage, and Agenda-setting in a Ghanaian Context. Canadian Journal of Communication 28,1: 43-66.

https://doi.org/10.22230/cjc.2003v28n1a1340

Landa, N. 2014. Investigating Sociolinguistic Factors Influencing the Blurring of Boundaries in Press Print Media Genres in Zimbabwe. Unpublished Doctoral Thesis, University of Fort Hare, Faculty of Social Sciences and Humanities.

Landa, N. \& S. Zhou 2018. A Critical Discourse Analysis of 'Religious Othering' in Pentecostalism: A Case of the Apostolic Faith Mission in Zimbabwe. In Machingura F., L. Togarasei \& E. Chitando (eds.): Pentecostalism and Human Rights in Contemporary Zimbabwe. Cambridge: Cambridge Scholars Publishing.

Landa, N., S. Zhou \& B. Tshotsho 2019. Interrogating the Role of Language in Clergy Sexual Abuse of Women and Girls in Zimbabwe. Journal for the Study of Religion 32,2.

https://doi.org/10.17159/2413-3027/2019/v32n2a5

McCombs, M.E. 2004. Setting the Agenda: The Mass Media and Public Opinion. Cambridge: Polity Press.

McCombs, M.E. 2005. A Look at Agenda-setting: Past, Present and Future. Journalism Studies 6,4: 543-557.

https://doi.org/10.1080/14616700500250438

McCombs, M.E., E. Lopez-Escobar \& J.P. Llamas 2000. Setting the Agenda of Attributes in the 1996 Spanish General Election. Journal of Communication 50,2: 77-92. https://doi.org/10.1111/j.1460-2466.2000.tb02842.x

McCombs, M.E \& D.L. Shaw 1972. The Agenda-setting Function of Mass Media. Public Opinion Quarterly 36,2: 176-187.

https://doi.org/10.1086/267990

McCombs, M.E \& S. Valenzuela 2007. The Agenda-Setting Theory. Cuadernos de Información 20: 44-50. Available at:

http://www.redalyc.org/ articulo.oa?id=97120369004 (Accessed on 27 March 2019.) https://doi.org/10.7764/cdi.20.111

Morna, C.L. 2002. Promoting Gender Equality in and through the Media: A Southern African Case Study. Expert Group Meeting on 'Participation 
and Access of Women to the Media, and the Impact of Media on, and its Use as an Instrument for the Advancement and Empowerment of Women. Beirut, Lebanon, 12 to 15 November 2002. United Nations Division for the Advancement of Women (DAW).

Mugugunyeki, M. 2014. Churches no Longer Safe for Women. The Standard.

Available at: https://www.thestandard.co.zw/2014/01/19/churches-

longer-safe-women/ (Accessed on 27 March 2019.)

NewsDay 2017a. HIV+ Pastor Caged 18 Years for Raping Congregant. 15 December.

NewsDay 2017b. Pastor Gets 60 Years for Preying on Congregant. 3 November.

Papadouka, M.E., N. Evangelopoulos \& G. Ignatow 2016. Agenda Setting and Active Audiences in Online Coverage of Human Trafficking. Information, Communication and Society 19,5: 655-672. Available at:

http://dx.doi.org/ 10.1080/1369118X.2016.1139615 (Accessed 27 March 2019.) https://doi.org/10.1080/1369118X.2016.1139615

Perloff, R.M. 1998. Political Communication: Politics, Press, and Public in America. New Jersey: Lawrence Erlbaum Associates.

Pietikainen, S. \& J. Hujanen 2003. At the Crossroads of Ethnicity, Place and Identity: Representations of Northern People and Regions in Finnish News Discourse. Media, Culture \& Society 25: 251-268.

https://doi.org/10.1177/0163443703025002517

Ragas, M.W. \& M. Roberts 2009. Agenda Setting and Agenda Melding in an Age of Horizontal and Vertical Media: A New Theoretical Lens for Virtual Brand Communities. Journalism and Mass Communication Quarterly 86,1: 45-56. https://doi.org/10.1177/107769900908600104

RTE News. Pope Francis will Meet Abuse Survivors during Visit to Ireland. Updated Thursday, 23 Aug 2018 09:36. Available at:

https://www.rte.ie/news/ 2018/0821/986443-pope-francis/ (Accessed on 7 April 2019.)

Rupapa, T. 2016. I was Never Raped: Magaya Accuser. The Herald. Available at: https://www.herald.co.zw/i-was-never-raped-magaya-accuser/

(Accessed on 27 March 2019.)

Scheufele, D.A. \& D. Tewksbury 2000. Framing, Agenda Setting, and Priming: The Evolution of Three Media Effects Models. Journal of Communication 57,1: 9-20.

https://doi.org/10.1111/j.0021-9916.2007.00326.x 
Sibanda-Moyo, N., E. Khonje \& M.K. Brobbey 2017. Violence against Women in South Africa: A Country in Crisis. Johannesburg: Centre for the Study of Violence and Reconciliation.

Stacey, W.A., S.E. Darnell \& A. Shupe 2000. How Much Clergy Malfeasance is Really Out There? A Victimization Survey of Prevalence and Perceptions. In Shupe A., W.A. Stacey \& S.E. Darnell (eds.): Bad Pastors: Clergy Misconduct in Modern America. New York: New York University Press.

Starosta, W.J. 1999. Critical Discourse Analysis and the Other. Journal of Communication 49,2: 145-147.

https://doi.org/10.1111/j.1460-2466.1999.tb02799.x

Supreme Court of Tasmania 2015. Annual Report 2014 - 2015. Available at: https://www.supremecourt.tas.gov.au/wpcontent/uploads/2018/11/SCoT_AnlRpt_1415.pdf

(Accessed on 27 March 2019.)

Tedesco, J.C. 2001. Issue and Strategy Agenda-setting in the 2000 Presidential

Primaries. American Behavioral Scientist 44,12: 2048-2067.

https://doi.org/10.1177/00027640121958483

Towindo, L. \& D. Matabvu 2016. Prophet Magaya Arrested on Rape Charge. Sunday Mail. Available at:

https://www.sundaymail.co.zw/prophet-magaya-arrested-on-rape-charge (Accessed on 27 March 2019.)

Trent, J.S. \& R.V. Friedenberg 2008. Political Campaign Communication: Principles and Practices. $6^{\text {th }}$ Edition. Plymouth: Rowman \& Littlefield Publishers Inc.

United Nations 1993. Declaration on the Elimination of Violence against Women. (UN Resolution 48/104.) Paper at the Proceedings of the $85^{\text {th }}$ Plenary Meeting. Geneva: United Nations General Assembly.

Van Dijk, T.A. 1988a. News Analysis: Case Studies of International and National News in the Press. Hillsdale, New Jersey: Lawrence Erlbaum.

Van Dijk, T.A. 1988b. News as Discourse. Hillsdale, New Jersey: Lawrence Erlbaum.

Vangshardt, T. 2009. The Agenda Setting Effect of the U.S. Mass Media during the 2008 Presidential Campaign. Copenhagen Business School.

Wanta, W. 1997. 'The Public and the National Agenda. New Jersey: Lawrence Erlbaum Associates.

Weaver, D. 2007. Thoughts on Agenda Setting, Framing, and Priming. Journal 
of Communication 57: 142-147.

https://doi.org/10.1111/j.1460-2466.2006.00333.x

Weaver, D., M. McCombs \& D.L. Shaw 2004. Agenda-setting Research:

Issues, Attributes, and Influences. In Kaid, L.I. (ed.): Handbook of

Political Communication Research. Mahwah, NJ: Erlbaum.

Weimann, G. \& H.B. Brosius 2016. A New Agenda for Agenda Setting in the

Digital Era. In Vowe, G. \& P. Henn (eds.): Political Communication in the Online World: Theoretical and Research Designs. New York:

Routledge. https://doi.org/10.4324/9781315707495-3

Young, R. \& K. McCarthy 2009. Why do Municipal Issues Rise on the Federal

Policy Agenda in Canada? Canadian Public Administration 52,3: 347-

370. https://doi.org/10.1111/j.1754-7121.2009.00087.x

Zhou, S., N. Landa \& I.N. Zhou 2017. Analysis of Media Roles in Bridging the Information Gap for Environmentally Sustainable Development in Zimbabwe. Eastern Africa Social Science Research Review 33: 2.

Zhou, S., C. Pfukwa \& N. Landa 2018. Of Prophets and Apostles: The Onomastic and Linguistic Implications of Using Titles as Names in Pentecostalism. In Machingura, F., L. Togaresei \& E. Chitando (eds.): Pentecostalism and Human Rights in Contemporary Zimbabwe. Cambridge: Cambridge Scholars Publishing. https://doi.org/10.1353/eas.2017.0009

Dr. Nhlanhla Landa Faculty of Social Sciences and Humanities. University of Fort Hare nlanda@ufh.ac.za

Dr. Sindiso Zhou Department of English Faculty of Social Sciences and Humanities University of Fort Hare szhou@ufh.ac.za 